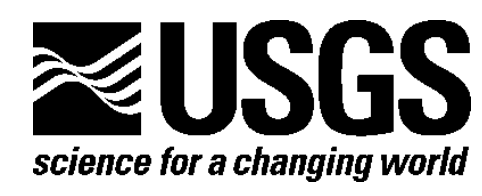

\title{
Computer Simulation of Reservoir Depletion and Oil Flow from the Macondo Well Following the Deepwater Horizon Blowout
}

By Paul A. Hsieh

Open-File Report 2010-1266

U.S. Department of the Interior

U.S. Geological Survey 


\section{U.S. Department of the Interior \\ KEN SALAZAR, Secretary}

\section{U.S. Geological Survey \\ Marcia K. McNutt, Director}

U.S. Geological Survey, Reston, Virginia: 2010

For product and ordering information:

World Wide Web: http://www.usgs.gov/pubprod

Telephone: 1-888-ASK-USGS

For more information on the USGS—-the Federal source for science about the Earth, its natural and living resources, natural hazards, and the environment:

World Wide Web: http://www.usgs.gov

Telephone: 1-888-ASK-USGS

Suggested citation:

Hsieh, Paul, 2010, Computer simulation of reservoir depletion and oil flow from the Macondo well

following the Deepwater Horizon blowout: U.S. Geological Survey Open-File Report 2010-1266, 18 p.

Any use of trade, product, or firm names is for descriptive purposes only and does not imply endorsement by the U.S. Government. 


\section{Contents}

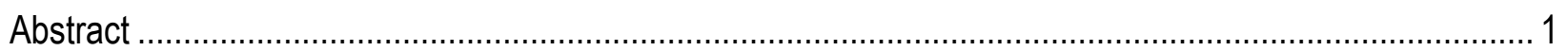

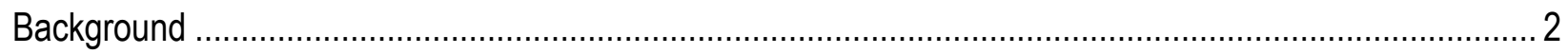

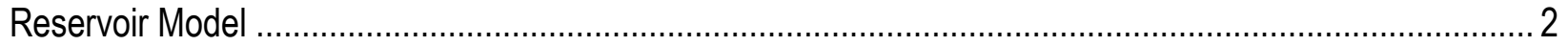

Reservoir Geometry and Conditions ........................................................................................ 2

Mathematical Formulation...................................................................................................... 3

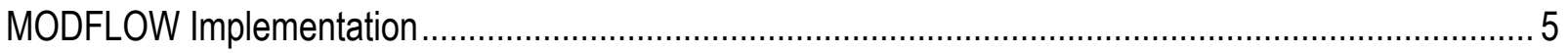

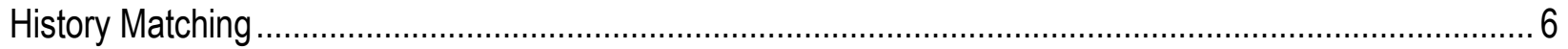

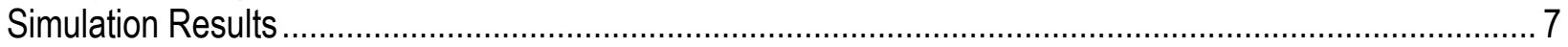

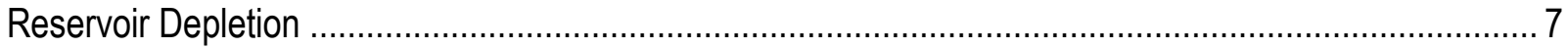

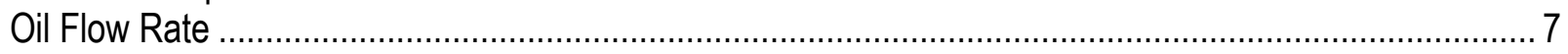

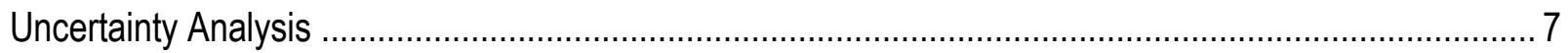

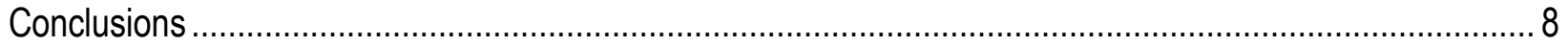

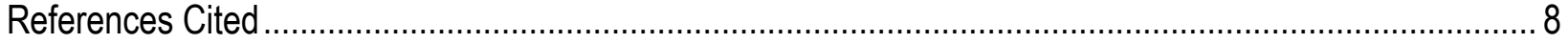

\section{Tables}

Table 1. Reservoir and fluid properties used in the reservoir simulation model.................................. 9

Table 2. Model parameters that are estimated by history matching................................................ 10

Table 3. Simulated oil flow rates and total volume of oil discharged along with 95-percent prediction intervals computed by PEST predictive analysis. .............................................................. 11

Table 4. Impact of \pm 25 -percent variation in parameter value on simulated initial flow rate, final flow rate, and total volume of oil discharged.

\section{Figures}

Figure 1. Oblique schematic view of the M56 oil reservoir.

Figure 2. Schematic vertical section showing flow of oil from M56 reservoir through the Macondo well and exiting at the top of the blowout preventer.

Figure 3. Map view of an example finite-difference grid of the oil reservoir. .......................................... 15

Figure 4. Horner plot of shut-in pressure in the capping stack of the Macondo well.............................. 16

Figure 5. Simulated reservoir pressure at the Macondo well face. ................................................... 17

Figure 6. Simulated volumetric flow rate of oil from the Macondo well in stock tank barrels per day $(\mathrm{stb} / \mathrm{d})$. 


\section{Conversion Factors}

\section{Oil Field Units to SI}

\begin{tabular}{lll}
\hline Multiply & By & To obtain \\
\hline foot (ft) & 0.3048 & meter $(\mathrm{m})$ \\
gallon (gal) & 0.0037854 & cubic meter $\left(\mathrm{m}^{3}\right)$ \\
Barrel $^{1}(\mathrm{bbl})$ & 0.15899 & cubic meter $\left(\mathrm{m}^{3}\right)$ \\
pound per square inch (psi) & 6.8948 & kilopascal $(\mathrm{kPa})$ \\
pound per gallon $(\mathrm{ppg})$ & 119.83 & kilogram per cubic meter $\left(\mathrm{kg} / \mathrm{m}^{3}\right)$ \\
centipoise $(\mathrm{cP})$ & 0.001 & pascal-second $(\mathrm{Pa} \cdot \mathrm{s})$ \\
millidarcy $(\mathrm{mD})$ & $9.8692 \times 10^{-16}$ & meter squared $\left(\mathrm{m}^{2}\right)$ \\
\hline
\end{tabular}

\section{SI to Oil Field Units}

\begin{tabular}{lll}
\hline Multiply & By & To obtain \\
\hline meter $(\mathrm{m})$ & 3.281 & foot $(\mathrm{ft})$ \\
cubic meter $\left(\mathrm{m}^{3}\right)$ & 264.17 & gallon $(\mathrm{gal})$ \\
cubic meter $\left(\mathrm{m}^{3}\right)$ & 6.2898 & Barrel $^{1}(\mathrm{bbl})$ \\
kilopascal $(\mathrm{kPa})$ & 0.14504 & pound per square inch $(\mathrm{psi})$ \\
kilogram per cubic meter $\left(\mathrm{kg} / \mathrm{m}^{3}\right)$ & 0.0083454 & pound per gallon $(\mathrm{ppg})$ \\
pascal-second $(\mathrm{Pa} \cdot \mathrm{s})$ & 1,000 & centipoise $(\mathrm{cP})$ \\
meter squared $\left(\mathrm{m}^{2}\right)$ & $1.01325 \times 10^{15}$ & millidarcy $(\mathrm{mD})$ \\
\hline
\end{tabular}

${ }^{1}$ Oil volume under reservoir conditions is measured in terms of reservoir barrels. Oil volume under surface conditions $\left(60^{\circ} \mathrm{F}\right.$ and $14.7 \mathrm{psi}$, or $15^{\circ} \mathrm{C}$ and $\left.101.325 \mathrm{kPa}\right)$ is measured in terms of stock tank barrels. When a quantity of oil is brought from reservoir conditions to surface conditions, the change in temperature and pressure and the release of gas bubbles cause the oil volume to decrease. The ratio of the oil volume under reservoir conditions to the volume under surface conditions is known as the formation volume factor and is denoted by $B$.

Temperature in degrees Fahrenheit $\left({ }^{\circ} \mathrm{F}\right)$ may be converted to degrees Celsius $\left({ }^{\circ} \mathrm{C}\right)$ as follows:

${ }^{\circ} \mathrm{C}=\left({ }^{\circ} \mathrm{F}-32\right) / 1.8$ 


\title{
Computer Simulation of Reservoir Depletion and Oil Flow from the Macondo Well Following the Deepwater Horizon Blowout
}

\author{
By Paul A. Hsieh
}

\begin{abstract}
This report describes the application of a computer model to simulate reservoir depletion and oil flow from the Macondo well following the Deepwater Horizon blowout. Reservoir and fluid data used for model development are based on (1) information released in BP's investigation report of the incident, (2) information provided by BP personnel during meetings in Houston, Texas, and (3) calibration by history matching to shut-in pressures measured in the capping stack during the Well Integrity Test. The model is able to closely match the measured shut-in pressures. In the simulation of the 86-day period from the blowout to shut in, the simulated reservoir pressure at the well face declines from the initial reservoir pressure of 11,850 pounds per square inch (psi) to 9,400 psi. After shut in, the simulated reservoir pressure recovers to a final value of 10,300 psi. The pressure does not recover back to the initial pressure owing to reservoir depletion caused by 86 days of oil discharge. The simulated oil flow rate declines from 63,600 stock tank barrels per day just after the Deepwater Horizon blowout to 52,600 stock tank barrels per day just prior to shut in. The simulated total volume of oil discharged is 4.92 million stock tank barrels. The overall uncertainty in the simulated flow rates and total volume of oil discharged is estimated to be \pm 10 percent.
\end{abstract}




\section{Background}

The computer simulation described in this report was undertaken to supplement the work of the Flow Rate Technical Group, a group of scientists and engineers led by U.S. Geological Survey (USGS) Director Marcia McNutt to estimate the flow of oil from the Macondo well following the Deepwater Horizon blowout on April 20, 2010. Much of the work of the Flow Rate Technical Group was carried out prior to July 15, 2010, the date when the Macondo well was shut in to begin the Well Integrity Test. The computer simulation described in this report was carried out to analyze the shut-in pressure data obtained during the Well Integrity Test in order to gain additional knowledge of the Macondo well and the oil reservoir. Simulation results of particular interest include (1) the assessment of reservoir depletion resulting from oil flow during the 86 days from blowout to shut in, (2) the estimate of oil flow rate from the well, and (3) the estimate of total volume of oil discharged.

A significant amount of data used in the development of the reservoir model described in this report were provided by BP personnel at meetings in Houston, Texas, during late June to early August 2010. Much of these data are considered proprietary and by Government regulation cannot be released. Although the proprietary data were included in the draft version of this report for USGS technical peer review, they are not included in this final release version in accordance with Government regulation.

\section{Reservoir Model}

\section{Reservoir Geometry and Conditions}

The Macondo well produces oil from an oil reservoir known as M56. According to the BP investigation report of the Deepwater Horizon blowout (BP, 2010, Appendix W, p. 17, fig. 1.6), the M56 oil reservoir consists of three oil-producing sand layers. The top of the reservoir is penetrated by the Macondo well at a depth of approximately 18,000 ft below sea surface. The combined pay thickness of the three oil-producing sand layers is approximately $90 \mathrm{ft}$. The initial reservoir pressure is 11,850 pounds per square inch (psi). The reservoir temperature is approximately $240^{\circ} \mathrm{F}$. As the bubble point of the oil in the reservoir is approximately $6,500 \mathrm{psi}$ (BP, 2010, Appendix W, p. 11), the reservoir is believed to be under single-phase (liquid oil) condition. Table 1 shows the reservoir and fluid properties used in the model. However, property values are not given in this report owing to their proprietary nature.

To construct the reservoir model, the bulk volume of reservoir containing the oil is estimated by

$$
V_{b}=\frac{V_{o} B}{\phi\left(1-S_{w}\right)},
$$

where

$V_{b} \quad$ is the bulk volume of reservoir containing the oil $\left[\mathrm{L}^{3}\right]$,

$V_{o} \quad$ is the volume of original oil in place $\left[\mathrm{L}^{3}\right]$,

$B \quad$ is the formation volume factor [dimensionless], 


$$
\begin{aligned}
& \phi \quad \text { is porosity [dimensionless], and } \\
& S_{w} \quad \text { is water saturation [dimensionless]. }
\end{aligned}
$$

The sedimentary history of the Gulf Coast in the vicinity of the Macondo well suggests that the oil-producing sands composing the M56 reservoir are submarine channel fills (Posamentier, 2003). In the model, the oil reservoir is assumed to be a long, narrow channel having a rectangular cross section (fig. 1). The vertical thickness $(b)$ of the channel is $90 \mathrm{ft}$. The horizontal length $(L)$ and width $(W)$ are initially unknown and are estimated by history matching of the Well Integrity Test. However, because $L \times W \times b$ must equal $V_{b}, L$ and $W$ are related by

$$
L \times W=\frac{V_{b}}{b}=\frac{V_{b}}{90 \mathrm{ft}} .
$$

The reservoir is assumed to be a closed system. In other words, all six faces of the channel are impermeable boundaries. Within the reservoir, the Macondo well location is defined by the coordinates $\left(x_{w}, y_{w}\right)$, which are initially unknown and are estimated by history matching.

\section{Mathematical Formulation}

The equation of oil flow in the reservoir is given by (after Matthews and Russell, 1967, p. 7, equation 2.12)

$$
\frac{\partial^{2} p}{\partial x^{2}}+\frac{\partial^{2} p}{\partial y^{2}}=\frac{\phi \mu c}{k} \frac{\partial p}{\partial t}
$$

where

$p \quad$ is pressure $\left[\mathrm{M} /\left(\mathrm{L} \cdot \mathrm{T}^{2}\right)\right]$,

$c \quad$ is the system compressibility $\left[\mathrm{L} \cdot \mathrm{T}^{2} / \mathrm{M}\right]$,

$k \quad$ is permeability $\left[\mathrm{L}^{2}\right]$,

$\mu \quad$ is oil viscosity $[\mathrm{M} /(\mathrm{L} \cdot \mathrm{T})]$,

$x, y \quad$ are Cartesian coordinates in the horizontal plane [L], and

$t \quad$ is time $[\mathrm{T}]$.

In applying equation 3 to the reservoir, the following conditions are assumed:

1. Flow of oil is under single-phase and isothermal conditions.

2. Reservoir properties (permeability, porosity, and compressibility) are homogeneous.

3. Permeability and viscosity are independent of pressure.

4. Permeability is isotropic.

Additional assumptions are given by Matthews and Russell (1967). These are standard in the analysis of pressure buildup and flow tests in wells and include assumptions that the reservoir is 
horizontal, the fluid compressibility is small and constant, and that pressure gradients within the reservoir are sufficiently small for Darcy's law to apply.

The system compressibility is computed as (after Matthews and Russell, 1967, p. 135, note 1)

$$
c=\left(1-S_{w}\right) c_{o}+S_{w} c_{w}+c_{f}
$$

where

$c_{o} \quad$ is oil compressibility $\left[\mathrm{L} \cdot \mathrm{T}^{2} / \mathrm{M}\right]$,

$c_{w} \quad$ is water compressibility $\left[\mathrm{L} \cdot \mathrm{T}^{2} / \mathrm{M}\right]$, and

$c_{f} \quad$ is effective formation (or pore) compressibility $\left[\mathrm{L} \cdot \mathrm{T}^{2} / \mathrm{M}\right]$.

Except for permeability, values of reservoir and fluid properties used in the reservoir model are assumed to be known (table 1). Permeability is estimated by history matching.

The volumetric flow rate of oil from the reservoir through the Macondo well and exiting the blowout preventer is modeled by the equation (see fig. 2)

$$
Q^{2}=C\left(p_{w}-p_{e}-\rho_{o} g H\right)
$$

where

$Q \quad$ is the volumetric flow rate of oil at reservoir conditions $\left[\mathrm{L}^{3} / \mathrm{T}\right]$,

$C \quad$ is a coefficient of pressure loss through the well $\left[\mathrm{L}^{7} / \mathrm{M}\right]$,

$p_{w} \quad$ is the reservoir pressure at the well face $\left[\mathrm{M} /\left(\mathrm{L} \cdot \mathrm{T}^{2}\right)\right]$,

$p_{e} \quad$ is the ambient pressure at the exit point of the blowout preventer $\left[\mathrm{M} /\left(\mathrm{L} \cdot \mathrm{T}^{2}\right)\right]$,

$\rho_{o} \quad$ is oil density $\left[\mathrm{M} / \mathrm{L}^{3}\right]$,

$g \quad$ is gravitational acceleration $\left[\mathrm{L} / \mathrm{T}^{2}\right]$, and

$H \quad$ is the elevation difference between the M56 reservoir and the exit point at the blowout preventer [L].

Equation 5 is similar to the Darcy-Weisbach equation (De Nevers, 1970), which relates the head loss due to friction along a given length of pipe to the square of the flow rate through the pipe. The value of the coefficient $C$ in equation 5 is initially unknown and is estimated by history matching. In the reservoir simulation, $C$ is kept constant for the entire period of well flow. This assumes that the changes in outlet configuration, such as cutting of the riser pipe, do not significantly impact the oil flow rate. For the Macondo well flow calculation, the ambient pressure at the exit point of the blowout preventer $\left(p_{e}\right)$ is $2,190 \mathrm{psi}$ and $H$ is $13,000 \mathrm{ft}$. The volumetric flow rate of oil at surface (stock tank) conditions is computed by dividing $Q$ by the formation volume factor, $B$. 


\section{MODFLOW Implementation}

The U.S. Geological Survey model known as MODFLOW-2000 (Harbaugh and others, 2000 ) is used to simulate oil flow in the M56 oil reservoir. Although MODFLOW-2000 was originally designed to simulate the flow of groundwater in aquifers, it can be readily adapted for simulating flow of oil in reservoirs under single-phase and isothermal conditions. The fluid flow equation solved by MODFLOW-2000 is analogous to equation 3, and can be written as

$$
\frac{\partial^{2} h}{\partial x^{2}}+\frac{\partial^{2} h}{\partial y^{2}}=\frac{S_{s}}{K} \frac{\partial h}{\partial t},
$$

where

$h \quad$ is hydraulic head [L],

$K \quad$ is hydraulic conductivity $[\mathrm{L} / \mathrm{T}]$, and

$S_{s} \quad$ is specific storage $[1 / \mathrm{L}]$.

For simulating oil flow, the quantities $h, K$, and $S_{s}$ are computed as

$$
\begin{aligned}
& h=\frac{p}{\rho_{o} g}+z, \\
& K=\frac{\rho_{o} g k}{\mu}, \\
& S_{s}=\rho_{o} g \phi c,
\end{aligned}
$$

where

$z \quad$ is the vertical elevation above a reference datum $[\mathrm{L}]$.

A modified version of the General-Head Boundary Package is used to simulate flow through the Macondo well, as expressed by equation 5. In its original version, the General-Head Boundary Package (see McDonald and Harbaugh, 1988, chapter 11) can be used to implement equation 5 if the exponent of the $Q$ term were 1 instead of 2 . To implement the $Q^{2}$ term, the Fortran source code of the General-Head Boundary Package is modified and the program recompiled.

Figure 3 is a map view of an example finite-difference grid of the oil reservoir, which is represented by a single $90-\mathrm{ft}$ thick model layer. The cell containing the Macondo well has a horizontal dimension of $1 \mathrm{ft}$ by $1 \mathrm{ft}$. The cell size increases away from the well to a maximum size of $100 \mathrm{ft}$ by $100 \mathrm{ft}$. During history matching, the grid is reconstructed as the well coordinates $\left(x_{w}, y_{w}\right)$ are varied. The simulation time step is 0.2 day. Well shut in is simulated by setting the coefficient $C$ in equation 5 to zero. 


\section{History Matching}

The parameter estimation program PEST version 10 (Doherty, 2004) is used to perform history matching - the adjustment of model parameters so that simulated pressures match measured pressures. (This procedure is also known as model calibration.) The estimated model parameters are shown in table 2. PEST implements a nonlinear least-squares regression method to estimate model parameters by minimizing the sum of squares of the differences between measured and simulated pressures:

$$
\Phi=\sum_{i=1}^{N}\left(p_{i}^{\text {mea }}-p_{i}^{\text {sim }}\right)^{2}
$$

where

$N \quad$ is the number of measurements [dimensionless],

$p_{i}^{\text {mea }}$ is the $i^{\text {th }}$ measured pressure $\left[\mathrm{M} /\left(\mathrm{L} \cdot \mathrm{T}^{2}\right)\right]$, and

$p_{i}^{\text {sim }} \quad$ is the $i^{\text {th }}$ simulated pressure $\left[\mathrm{M} /\left(\mathrm{L} \cdot \mathrm{T}^{2}\right)\right]$

PEST uses the Gauss-Marquardt-Levenberg method to minimize $\Phi$. Details of this method are given in the PEST user's manual (Doherty, 2004).

The pressure data used for history matching were measured during the Well Integrity Test, which began on July 15, 2010. At 2:20 p.m. Central Daylight Time, the final turn on the choke was closed and the Macondo well was shut in. Shut-in pressure was measured continuously by two pressure gages installed in the capping stack. Pressure data from the PT-3K1 transducer were nearly identical to pressure data from the PT-3K-2 transducer, except the former gave a pressure reading that was approximately 100 psi lower than that from the latter. For history matching, shut-in pressures measured by the PT-3K-2 transducer are used. The simulated shut-in pressure in the capping stack is calculated by subtracting $\rho_{o} g H$ from the simulated reservoir pressure at the well face to adjust for the elevation difference between the M56 reservoir and the pressure gage in the capping stack. The Well Integrity Test ended on August 3, 2010, when heavy mud was injected into the Macondo well to initiate the "static kill" operation.

Figure 4 is a Horner plot showing the simulated shut-in pressures in the capping stack. The horizontal axis of the Horner plot shows the quantity $\left(t_{p}+\Delta t\right) / \Delta t$, where $t_{p}$ is the period of oil flow (86 days), and $\Delta t$ is the elapsed time since shut in. Note that on the horizontal axis, time increases to the left. The simulated pressures closely match the continuously measured pressures - the standard error of the residuals (differences between simulated and measured pressures) is 2.3 psi. However, the continuously measured pressures used for history matching are not shown in figure 4 owing to their proprietary nature. Instead, figure 4 shows only those pressure readings that were announced in daily Government press releases (http://www.restorethegulf.gov/news/press-releases) and in BP technical briefings (http://www.bp.com/sectiongenericarticle.do? categoryId=9034442\&contentId=7063846). 


\section{Simulation Results}

\section{Reservoir Depletion}

Figure 5 shows the simulated reservoir pressure at the Macondo well face. The origin of the time axis corresponds to April 20, 2010, the date of the Deepwater Horizon blowout. The initial reservoir pressure is 11,850 psi. Immediately after the blowout, the simulated pressure drops rapidly to approximately $11,000 \mathrm{psi}$ and then follows a steady decline to 9,400 psi on day 86 , just prior to shut in. After shut in, the simulated pressure recovers and eventually stabilizes at $10,300 \mathrm{psi}$. The pressure does not recover back to the initial pressure owing to reservoir depletion from 86 days of oil discharge.

\section{Oil Flow Rate}

Figure 6 shows the simulated volumetric flow rate of oil for surface conditions (expressed in stock tank barrels per day). Note that this flow rate is obtained by dividing the simulated flow rate under reservoir conditions, $Q$, by the formation volume factor, $B$. The simulated initial volumetric flow rate of oil is 63,600 stock tank barrels per day. As the reservoir depletes, the flow rate decreases to 52,600 stock tank barrels per day on day 86 , just prior to shut in. The simulated total volume of oil discharged over the 86-day period from blowout to shut in is 4.92 million stock tank barrels.

\section{Uncertainty Analysis}

After history matching, the program PEST is run in "predictive analysis mode" to assess the predictive uncertainty of the reservoir model (see Doherty, 2004, chapter 6). In this context, a "prediction" is simply a model-simulated quantity that is not measured - there is no implication that the simulated quantity is to occur in the future. Three simulated quantities are of particular interest: (1) the initial oil flow rate, just after the blowout; (2) the final oil flow rate, just before shut in; and (3) the total volume of oil discharged. Table 3 gives the predictive uncertainty of these simulated quantities in terms of 95-percent prediction intervals. Note that all three intervals are relatively narrow - the upper or lower limits are no more than a few percent higher or lower than the corresponding simulated value. The narrow intervals are largely due to the close match between simulated and observed pressures and the low degree of nonuniqueness in the estimated parameters.

The prediction intervals given in table 3, however, do not fully characterize the uncertainty in the simulated values. In calculating these intervals, it is assumed that the values of the reservoir and fluid properties given in table 1 are known. However, quantities such as original oil in place are, in fact, best estimates and are subject to uncertainty. To evaluate the impact of parameter uncertainty on the simulated flow rates and total volume of oil discharged, each reservoir or fluid property in table 1 is varied by \pm 25 percent, except for oil density, which is varied by \pm 10 percent (because a \pm 25 -percent variation in oil density is considered too extreme). For each parameter variation, history matching is re-performed, and the simulation results are tabulated in table 4 . As shown by the table, the impact of the parameter variation ranges from 0 (no impact) to \pm 25 percent of the simulated flow rates and total volume of oil discharged. On the basis of these results, the overall uncertainty in the simulated flow rates and total volume of oil discharged is estimated to be \pm 10 percent. 


\section{Conclusions}

The reservoir model presented in this report simulates oil discharge from the Macondo well following the Deepwater Horizon blowout and pressure recovery after the well was shut in. During the 86-day period of oil discharge, the simulated reservoir pressure at the well face declines from the initial reservoir pressure of $11,850 \mathrm{psi}$ to $9,400 \mathrm{psi}$. After shut in, the simulated reservoir pressure recovers to a final value of $10,300 \mathrm{psi}$. The pressure does not recover back to the initial pressure owing to reservoir depletion from the oil discharge. The simulated oil flow rate declines from 63,600 stock tank barrels per day just after the Deepwater Horizon blowout to 52,600 stock tank barrels per day just prior to shut in. The simulated total volume of oil discharged is 4.92 million stock tank barrels. Analysis of the predictive uncertainty of the reservoir model suggests that the 95-percent prediction intervals of the simulated flow rates and total volume of oil discharged are relatively narrow - the upper or lower limits are no more than a few percent higher or lower than the corresponding simulated value. However, these prediction intervals do not fully characterize the uncertainty in the simulated values. If uncertainties in reservoir and fluid properties are taken into account, the overall uncertainty in the simulated flow rates and total volume of oil discharged is estimated to be \pm 10 percent.

\section{References Cited}

BP, 2010, Deepwater Horizon accident investigation report, September 8, 2010, accessed October 5, 2010 at http://www.bp.com/sectiongenericarticle.do? categoryId=9034902\&contentId $=7064891$.

De Nevers, Noel, 1970, Fluid mechanics: Reading, Pa., Addison-Wesley, 514 p.

Doherty, John, 2004, PEST model-independent parameter estimation user manual, (5th ed.): Watermark Numerical Computing, variously paged, accessed October 5, 2010, at http://www.pesthomepage.org/Downloads.php.

Harbaugh, A.W., Banta, E.R., Hill, M.C., and McDonald, M.G., 2000, MODFLOW-2000, the U.S. Geological Survey modular ground-water model - user guide to modularization concepts and the ground-water flow process: U.S. Geological Survey Open-File Report 00-92, 121 p., accessed October 5, 2010, at http://water.usgs.gov/nrp/gwsoftware/modflow2000/ofr00-92.pdf.

Matthews, C.S., and Russell, D.G., 1967, Pressure buildup and flow test in wells: New York, Society of Petroleum Engineers of AIME, $167 \mathrm{p}$.

McDonald, M.G., and Harbaugh, A.W., 1988, A modular three-dimensional finite-difference ground-water flow model: U.S. Geological Survey Techniques of Water-Resources Investigations, book 6, chap. A1, 586 p., accessed October 5, 2010, at http://pubs.usgs.gov/twri/twri6al/.

Posamentier, H.W., 2003, Depositional elements associated with a basin floor channel-levee system - case study from the Gulf of Mexico: Marine and Petroleum Geology, v. 20, p. 677690. 
Table 1. Reservoir and fluid properties used in the reservoir simulation model.

[Property values used in the reservoir model are not given in this report owing to their proprietary nature]

\section{Reservoir or fluid property}

Original oil in place

Formation volume factor, $B$

Porosity, $\phi$

Effective formation (or pore) compressibility, $c_{f}$

Oil viscosity, $\mu$

Oil compressibility, $c_{o}$

Oil density, $\rho_{o}$

Water saturation, $S_{w}$

Water compressibility, $c_{w}$ 
Table 2. Model parameters that are estimated by history matching.

[See figure 1 for definition of $L, W, x_{w}$, and $y_{w}$. Estimated values are not given in this report because they are derived from proprietary data]

Model parameter

Horizontal length of reservoir, $L$

Horizontal width of reservoir, $W$

X-coordinate of Macondo well, $x_{w}$

Y-coordinate of Macondo well, $y_{w}$

permeability, $k$

Coefficient of pressure loss in well, $C$ 
Table 3. Simulated oil flow rates and total volume of oil discharged along with 95-percent prediction intervals computed by PEST predictive analysis.

\begin{tabular}{|c|c|c|c|}
\hline Simulated quantity & Simulated value & $\begin{array}{l}\text { 95-percent } \\
\text { Minimum }\end{array}$ & $\begin{array}{l}\text { ediction interval } \\
\text { Maximum }\end{array}$ \\
\hline Initial oil flow rate (stock tank barrels/day) & 63,600 & 62,800 & 64,200 \\
\hline Final oil flow rate (stock tank barrels/day) & 52,600 & 51,900 & 53,100 \\
\hline Total volume of oil discharged (stock tank barrels) & $4.92 \times 10^{6}$ & $4.85 \times 10^{6}$ & $4.97 \times 10^{6}$ \\
\hline
\end{tabular}


Table 4. Impact of \pm 25 -percent variation in parameter value on simulated initial flow rate, final flow rate, and total volume of oil discharged.

$[\%$, percent $]$

Impact of $\pm 25 \%$ variation in parameter value on

Parameter being varied

Original oil in place

Formation volume factor, $B$

Porosity, $\phi$

Effective formation (or pore)

compressibility, $c_{f}$

Oil viscosity, $\mu$

Oil compressibility, $c_{o}$

Oil density, $\rho_{o}$

Water saturation, $S_{w}$

Water compressibility, $c_{w}$
Initial flow rate

$\pm 25 \%$

0

0

$$
\pm 12 \%
$$

0

$\pm 13 \%$

$\pm 20 \%{ }^{*}$

$\pm 1 \%$

$\pm 0.3 \%$
Final flow rate

$\pm 25 \%$

0

0

$\pm 12 \%$

0

$\pm 13 \%$

$\pm 20 \%{ }^{*}$

$\pm 1 \%$

$\pm 0.3 \%$

\section{Total volume}

$\pm 25 \%$

0

0

$\pm 12 \%$

0

$\pm 13 \%$

$\pm 20 \%{ }^{*}$

$\pm 1 \%$

$\pm 0.3 \%$

* Oil density varied by \pm 10 percent. 


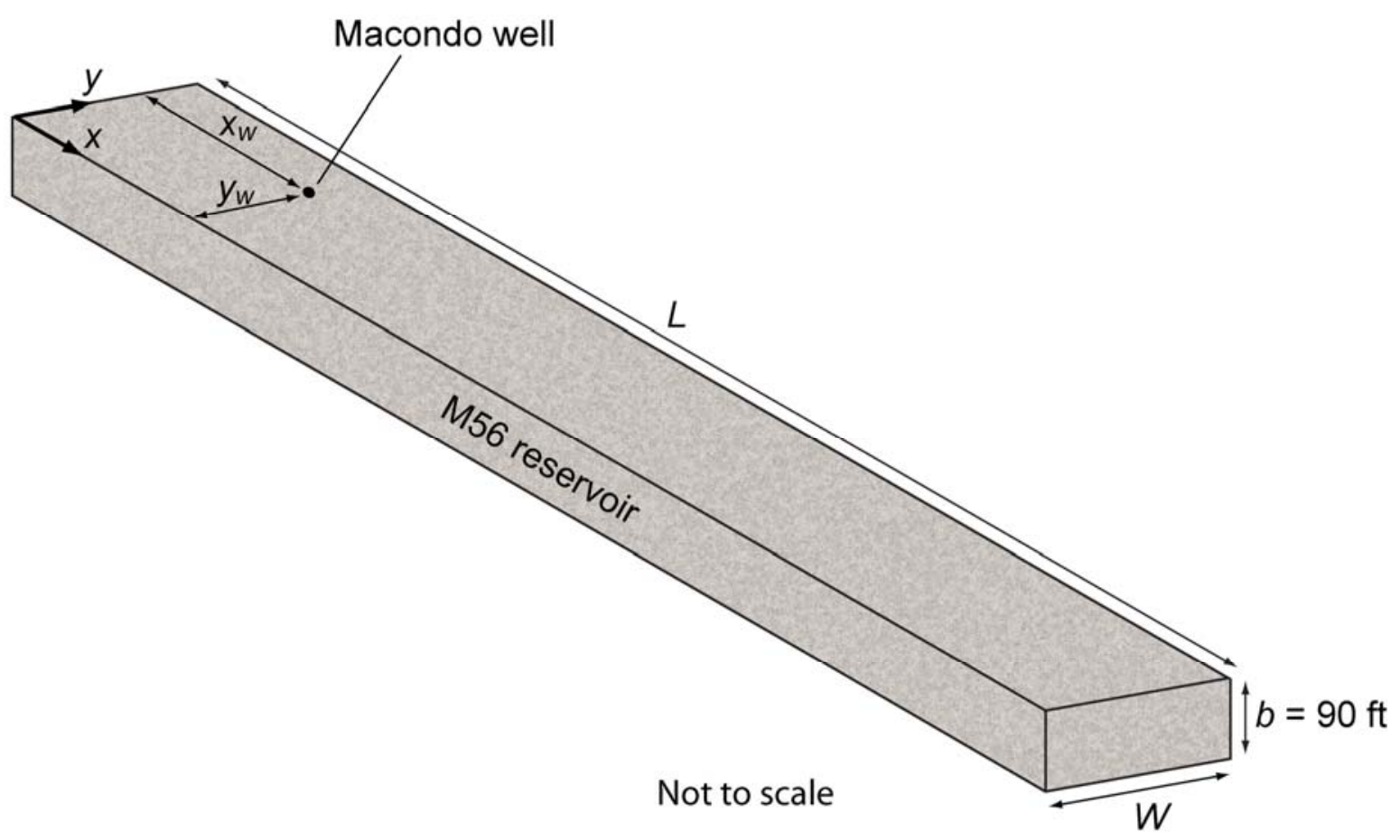

Figure 1. Oblique schematic view of the M56 oil reservoir. 


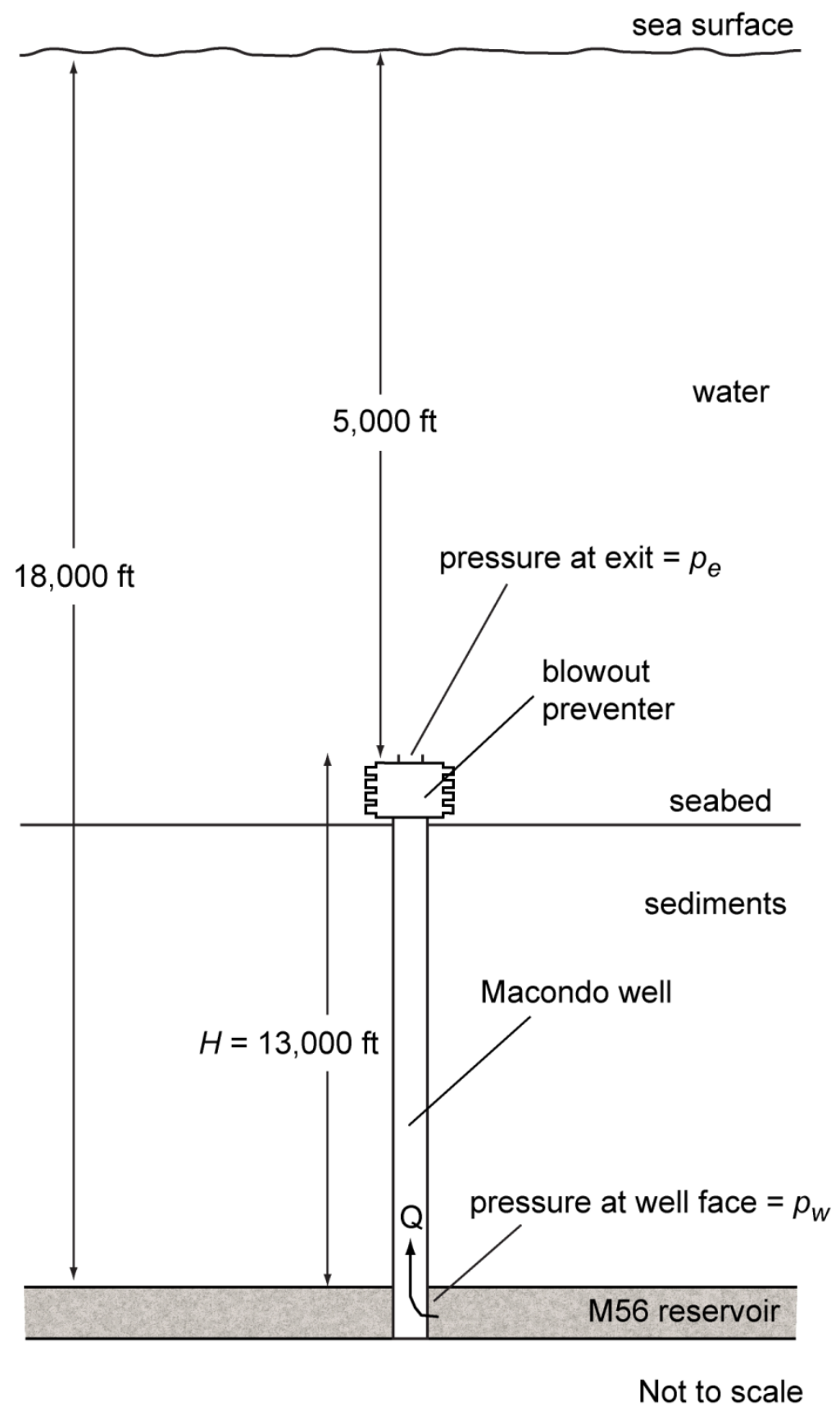

Figure 2. Schematic vertical section showing flow of oil from M56 reservoir through the Macondo well and exiting at the top of the blowout preventer. 


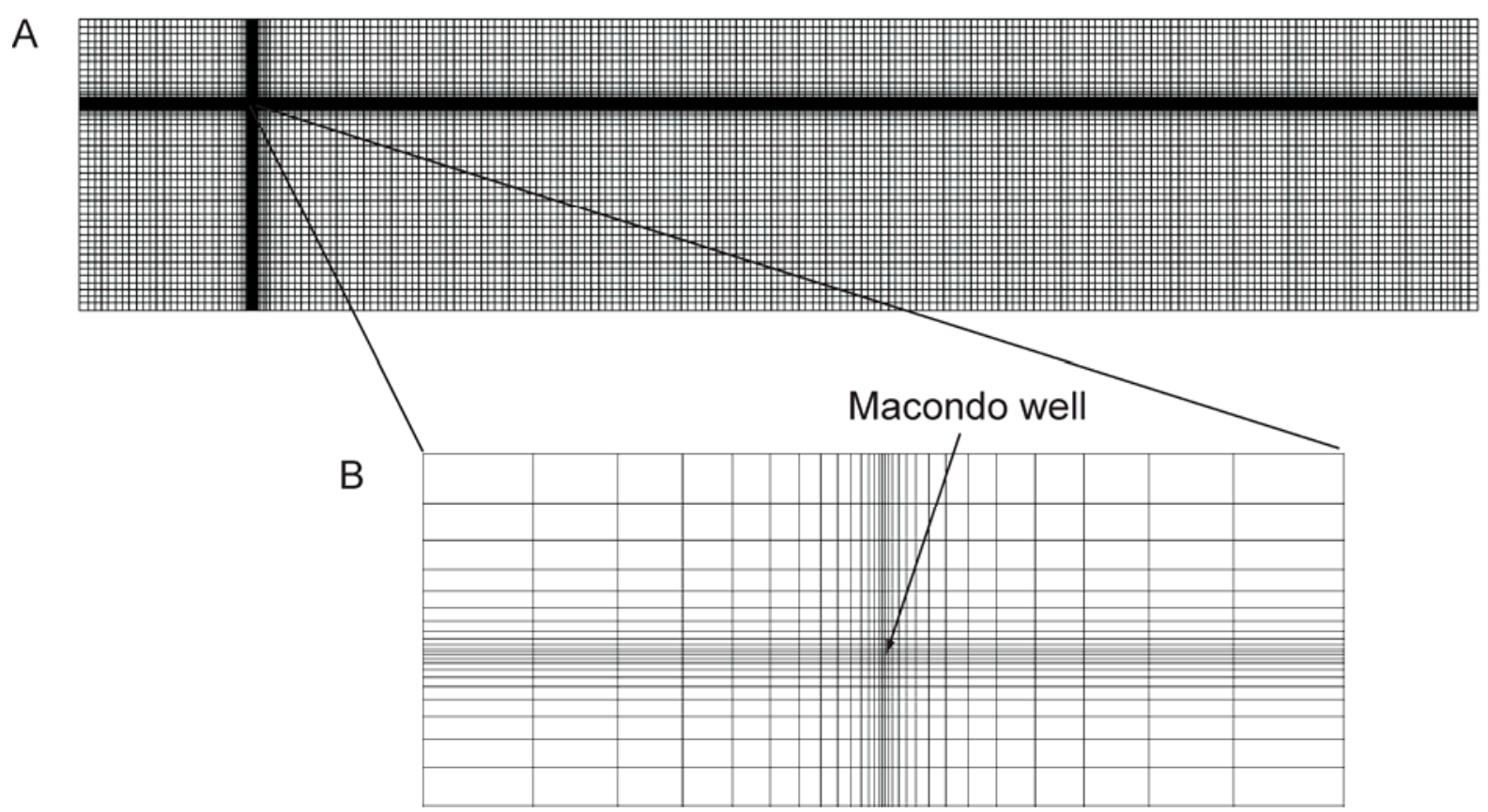

Figure 3. Map view of an example finite-difference grid of the oil reservoir. $A$, Entire grid. $B$, Detailed view of a small portion of the grid in the vicinity of the Macondo well. 


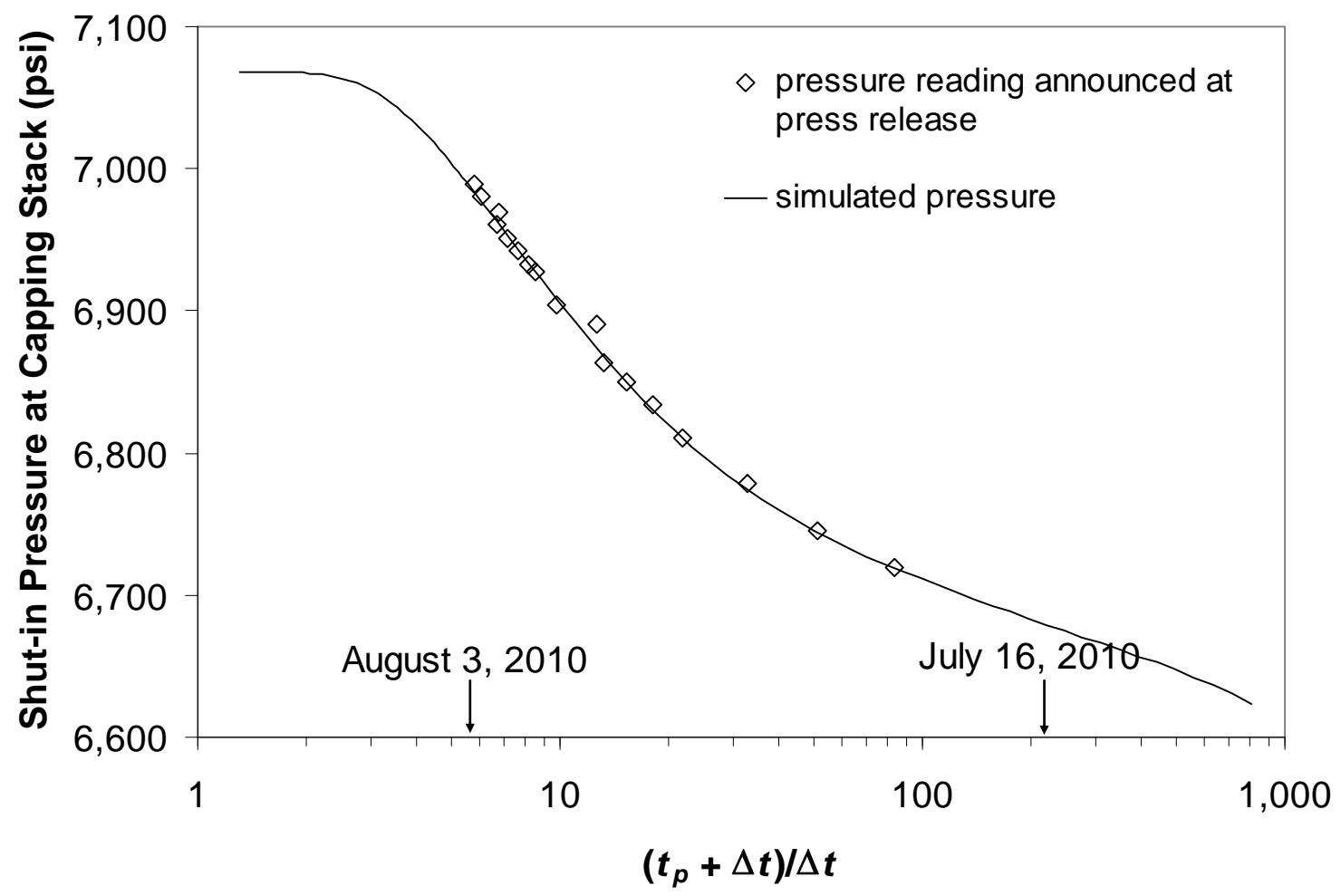

Figure 4. Horner plot of shut-in pressure in the capping stack of the Macondo well. $t_{t}$ is the period of oil flow, which is 86 days. $\Delta t$ is elapsed time since shut in. Note that time increases to the left on the horizontal axis. The solid line shows the simulated shut-in pressure in the capping stack. The simulated pressures closely match the continuously measured pressures, which are not given in this report owing to their proprietary nature. Instead, the diamond symbols show pressure readings that were announced in daily Government press releases and in BP technical briefings. 


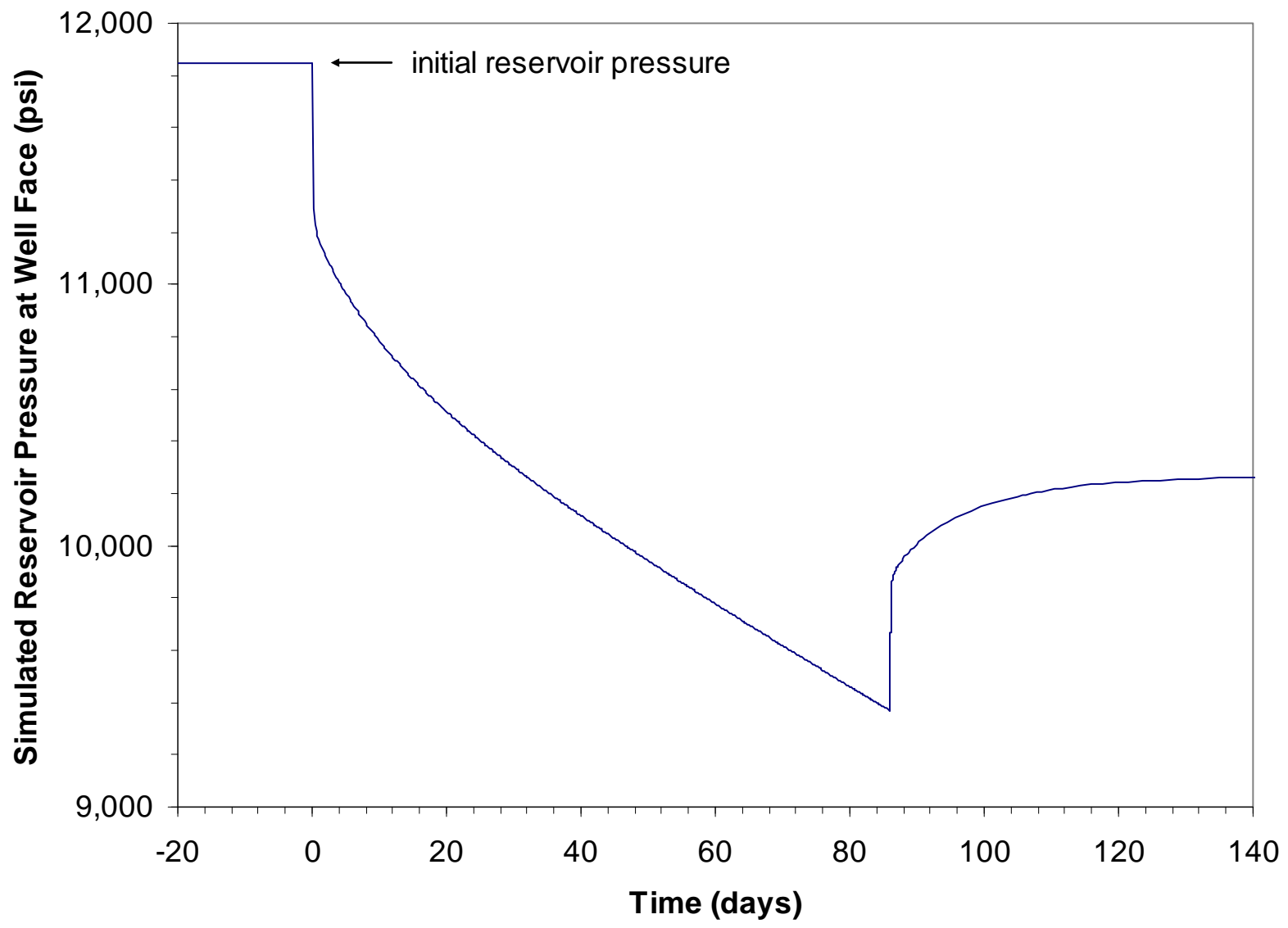

Figure 5. Simulated reservoir pressure at the Macondo well face. The origin of the time axis $(t=0)$ corresponds to April 20, 2010, the date of the Deepwater Horizon blowout. 


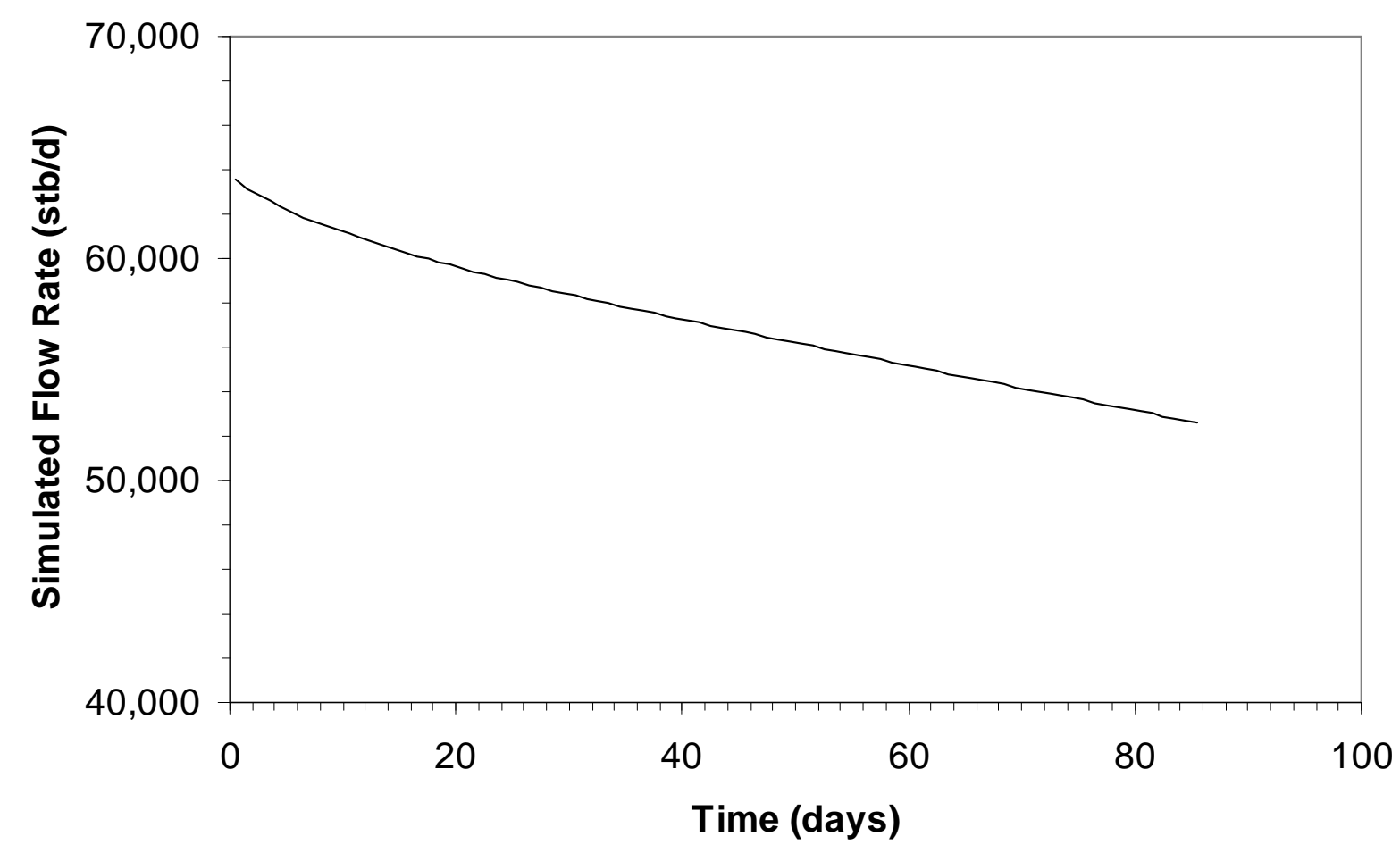

Figure 6. Simulated volumetric flow rate of oil from the Macondo well in stock tank barrels per day (stb/d). This flow rate is obtained by dividing the simulated flow rate under reservoir conditions $(Q)$ by the formation volume factor $(B)$. The origin of the time axis $(t=0)$ corresponds to April 20,2010, the date of the Deepwater Horizon blowout. 